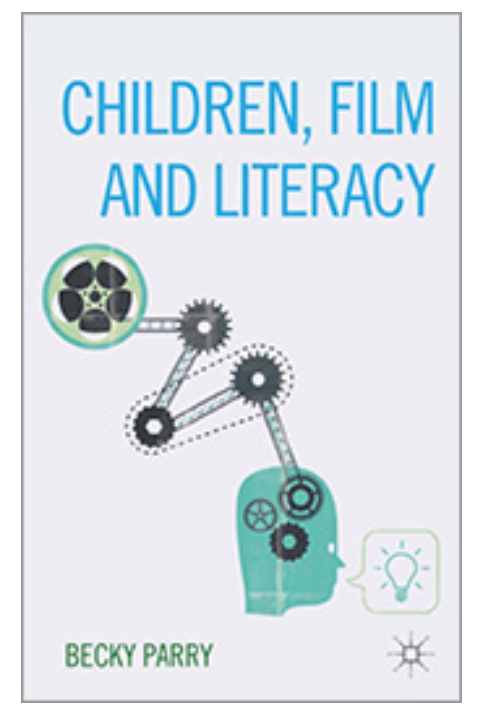

\section{KARNEVALISTISIA \\ KERTOMUKSIA \\ - LASTENELOKUVAN MONET MAHDOLLISUUDET}

\author{
Becky Parry (2013) Children, Film and Literacy. Hampshire: Palgrave
} Macmillan. 228 s.
Becky Parry pyrkii väitöstutkimuksessaan Children, Film and Literacy avaamaan yhteyksiä elokuvan ja lukutaidon välillä sekä perustelemaan elokuvakasvatuksen ja lastenelokuvan merkitystä laajasti ymmärretyn lukutaidon kehittämiselle. Vaikka teos on julkaistu jo joitakin vuosia sitten, se edustaa edelleen tervetullutta elokuvakasvatuksen ja lastenelokuvan tutkimusta mediakasvatuksen akateemisella kentällä.

Parryn keskeinen argumentti on, että lasten ymmärrys narratiiveista ja kertomuksen rakenteesta rakentuu nimenomaan lastenelokuvan kautta. Hän ei väitä elokuvan olevan lapsille muita populaarikulttuurin muotoja merkittävämpi media, vaan näkee elokuvan vaikutuksen olevan suurin nimenomaan sen merkityksessä lasten kertomusten ymmärtämisen rakentumiseen. Hän todentaa teesejään koulussa keräämällään tutkimusaineistolla, joka koostuu sekä lasten kirjoittamista teksteistä että elokuvista. Children, Film and Literacy -teoksen kiinnostavinta antia onkin lasten omien kertomusten ja elokuvien esiin tuominen ja pohdinta elokuvakulttuurin vaikutuksesta niihin. Parryn tutkimusaineistosta nousee esiin myös se, miten lapset ovat elokuvia katsomalla oppineet ja omaksuneet monet audiovisuaalisen kerronnan keinot. Parry esittääkin, että lapset oppivat lukemaan elokuvia ja nauttimaan elokuvista katsomalla niitä. Hän vastaa tutkimuksessaan kysymyksiin, mitä ja miten lapset oppivat narratiivista uppoutumalla lastenelokuvaan. Parry lähestyy tutkimuskysymyksiään lapsilähtöisen tutkimusmenetel- män avulla, osallistamalla tutkimuskohteensa. Tutkimustulosten raportoinnissa kuuluukin hyvin lasten ääni, jonka esiintuomisessa Parryn opettajakokemuksella on suuri merkitys. Parryn kouluille asettama vaatimus luovien ja dialogisten tilojen luomisesta kouluihin lasten omaehtoisen toiminnan ja motivaation tukemiseksi saattaa vaikuttaa itsestään selvältä, mutta kirja toimii hyvänä muistutuksena elokuvan merkityksestä ja potentiaalista opetuksessa.

\section{Elokuva koulussa}

Parryn mukaan äidinkielen opetukselle olisi merkittävää hyötyä, jos lasten kuluttamat sisällöt otettaisiin osaksi kouluopetusta tai ainakin annettaisiin niille arvo luokkahuoneessa. Lasten oppimistulokset voisivat parantua, jos he voisivat vapaasti ammentaa heille merkityksellisen kulttuuriin parista vaikutteita esimerkiksi kouluaineisiin ja muihin tehtäviin. Parry tuo tutkimuksessaan esiin lasten valtavan kompetenssin ja osaamisen, joka liittyy populaarikulttuurin konventioihin, hahmoihin ja narratiivisiin rakenteisiin. Tätä potentiaalia hän kannustaa hyödyntämään kouluissa. Parryn kritiikki brittiläistä koulujärjestelmää kohtaan on kovaa ja arvostelun kohteeksi joutuukin erityisesti kirjallisen- ja korkeakulttuurin ylivalta koulussa. Liikkuvaan kuvaan perustuvan tarinankerronnan ja tarinan muodon tunnustaminen koulukontekstissa auttaisi erityisesti niitä lapsia, joille kirjallisen muodon hallitseminen on hankalaa. 
Parry suhtautuu epäillen kriittisen medialukutaidon vaatimuksiin elokuvan kohdalla. Hänen mielestään on erikoista, että populaarikulttuurin tuotteet eivät ole samanarvoisessa asemassa tekstianalyysin kohteena kuin vaikkapa runous tai muut kirjallisen kulttuurin tuotteet. Mediakasvatuksesta tutut kysymykset tulisi yhtä lailla osoittaa kirjallisen kulttuurin tuotteille ja vastaavasti kirjallisuusanalyysille varattu analyysivälineistö tulisi ulottaa lapsille läheisiin populaarikulttuurin tuotteisiin. Englannissa Parryn argumentit tuntuvat varmasti kärkevimmiltä ja provosoivimmilta. Suomalaisen opetussuunnitelman ja erityisesti sen monilukutaitokäsitteen näkövinkkelistä vaatimukset eivät ole mitenkään radikaaleja, sisältäähän monilukutaidon pedagogiikka sekä laajan tekstikäsityksen audiovisuaalisine lukutaitoineen että vaatimuksen lasten elämismaailman huomioimisesta kouluopetuksessa.

\section{Lastenelokuvan karnevaali}

Ansiokkainta kirjassa on sen tapa nostaa esiin lasten oma kulttuuri. Parry selvästi arvostaa lastenkulttuuria ja lastenelokuvaa. Usein trivialisoitu ja ylenkatsottukin lastenelokuva on hänelle tärkeä kulttuurin alue. Ongelmallista Parryn lähestymistavassa on toisaalta liian rajattu ja toisaalta liian lavea lastenelokuvan määritelmä. Lähes kaikki kirjassa mainitut esimerkkielokuvat edustavat Hollywoodtuotantoa, Disney etunenässä. Toisaalta hän lukee lastenelokuviksi myös esimerkiksi Star Warsin ja Spidermanin kaltaiset sci-fi- ja supersankariseikkailut. Lastenelokuvan määritelmä olisin kaivannut selkeästi enemmän pohdintaa ja jäntevöittämistä. Jonkin verran Parry setvii määrittelyviidakkoa, mutta kompastelee erityisesti pyrkiessään erottamaan lasten- ja perheelokuvat toisistaan. Myöskään usein käytetty "elokuvia lapsista" ja "elokuvia lapsille" erottelu ei välttämättä toimi toivotulla tavalla. Määritelmät riippuvat kuitenkin usein siitä, otetaanko lähtökohdaksi kaupallinen kategoria, tekijän intentio vai kohdeyleisön reaktiot.

Parry huomioi lastenkirjallisuuden tutkimuksen ottaneen viime vuosina suuria harppauksia ja toivoisi samaa myös lastenelokuvan tutkimukselta. Hän peräänkuuluttaa monipuolisempaa ja rikkaampaa lastenelo- kuvatutkimusta, joka asettaisi elokuvan muun lastenkulttuurin rinnalle. Parry huomauttaa esim. että lastenelokuvaa tutkitaan usein, ei niinkään taiteena tai teoksena, vaan ideologisena välineenä. Tutkimustendenssi siis on hyvinkin linjassa lastenelokuvan elokuvakulttuurisen aseman kanssa. Itse näkisin mielelläni lastenelokuvatutkimuksen samanarvoisena muun elokuvatutkimuksen kanssa ja lastenelokuvan tasavertaisena osana elokuvakulttuuria, jossa lastenelokuvalla on edelleen hieman väheksytty osa ehkä kaupallista potentiaalia lukuun ottamatta.

Parry ei jätä huomiotta vaikkapa Disneytuotannon arveluttavia piirteitä rasismista seksismiin, mutta ei lähde siitä olettamuksesta, että elokuvakasvatuksen tärkein tehtävä on kasvattaa (lapsi)yleisön elokuvamakua ja kouluttaa heidät katsomaan mediaa kriittisesti. Parry tähdentää lasten oman kokemuksen merkitystä ja kuuntelemista. Parry antaa paljon tilaa lasten kokemusmaailmalle ja näkemyksille ja hän painottaa lasten käyttävän ja tulkitsevan populaarikulttuuria omista lähtökohdistaan. Aikuisen mielestä ideologisesti epäilyttävä sisältö saattaakin lasten medialeikeissä muuttua emansipaation välineeksi tai vastakulttuurin käsikassaraksi. Lastenelokuvissa on usein karnevalistista, väkivaltaista ja rajoja ylittävää huumoria ja lastenelokuvissa lapset yleensä voimautuvat vastustamaan aikuisauktoriteettia.

Parry painottaakin elokuvan ja lasten populaarikulttuurin itseisarvoa lasten elämässä ja itseilmaisussa. Hän myös korostaa katsomista aktiivisena prosessina, joka itsessään opettaa ja saa lapset sisäistämään ja tiedostamaan kerronnallisia ja lajityypillisiä konventioita ja elokuvien tyylillisiä piirteitä. Parry havainnoi, että saadessaan kirjoittaa vapaasti lapset omaksuivat lasten elokuvien konventioita ja kuvitteellisia maailmoja, joihin he heijastivat omia kokemuksiaan ja joita vasten he tutkivat omaa identiteettiään.

Parry kiinnittää aiheellisesti huomiota lasten kulttuurin vastakulttuuriseen luonteeseen. Hän myös muistuttaa, miten mahdotonta aikuisen on lopulta asettua lapsen asemaan. Tyypillisessä tilanteessa vanhempi haluaa tutustuttaa lapsensa oman lapsuutensa ja elää uudestaan lapsuuden maagisia hetkiä. Parry muistuttaa miten tärkeä lapsille on myös antaa 
oma tilansa ja mahdollisuutensa omaehtoiseen kulttuuriin, jolle yleensä oleellista on aikuisille käsittämättömänä ja jopa haitallisena näyttäytyminen. Lastenelokuva tekstinä voi tarjota hedelmällisen tilan neuvottelulle lapsista, lapsuudesta ja vanhemmuudesta. Lastenelokuvat ja muu lasten populaarikulttuuri voi myös toimia tilana, jossa lapset tekevät eroa itsensä ja aikuisten välille ja kehittävät omat leikilliset, mielikuvitukselliset ja rajoja rikkovat vastauksensa aikuisten luomalle kulttuurille.

\section{Lapset elokuvantekijöinä}

Parry käytti yhtenä aineistonkeruumetodina työpajamuotoista työskentelyä, jossa lapset pääsivät tekemään omia elokuviaan. Erityisesti tässä vaiheessa lapset käyttivät lähteinään lastenelokuvien kerronnallisia elementtejä, tapahtumapaikkoja ja juonikuvioita. Lapset osoittivat olevansa hyvin perillä kerronnan keinoista ja säännöistä, mutta he myös muuntelivat niitä omiin tarpeisiinsa hyvin luovasti. Lapset osasivat myös hyödyntää elokuvan tyylillisiä keinoja kuten väriä, ääntä ja musiikkia ideoidensa välittämisessä. Parry ei kuitenkaan riittävästi ja tarpeeksi yksityiskohtaisesti avaa omaa osuuttaan lasten ohjaamisessa. Hieman hämäräksi jää, kuinka paljon elokuvatuotannot olivat täysin lasten aloitteesta tehtyjä. Se kuitenkin tulee selväksi, että Parry on pyrkinyt välttämään sensurointia. Tärkeä huomio Par- ryltä on muistuttaa lasten aidon kuulemisen tärkeydestä elokuvaprojekteja suunniteltaessa, helposti "lasten tekemästä" elokuvasta tuleekin vain aikuisten esteettistä ja moraalista näkökulmaa heijastava koulutyö.

Parry kritisoi suoraan kotimaansa koulutus- ja opetussuunnitelmapolitiikkaa, joka on omiaan rajaamaan lasten populaarikulttuurin koulun ulkopuolelle. Hänellä on sanansa sanottavana myös brittiläisestä lastenelokuvatuotannosta, jolle hän kaipaisi enemmän tukea. Vaikka Parry varoittaa ideologisesta amerikkalaisen lastenkulttuurin demonisoimisesta, hän on myös sitä mieltä, että lapset ansaitsevat nähdä elokuvia tutusta ympäristöstään, elokuvia, jotka tarjoavat enemmän samastumispintoja. Hän kiinnittää huomiota myös Suomessa tuttuun mediakasvatuksen painopisteongelmaan, jossa uudet teknologiat ja niiden opetuskäyttö kyllä huomioidaan, mutta sisältö, kuten teknologiavälitteiset visuaaliset ja multimodaaliset narratiivit sivuutetaan. Parryn mielestä kouluopetus hyötyisi erityisesti siitä, jos lasten annettaisiin hyödyntää intuitiivista ymmärrystään tarinankerronnasta. Elokuva on Parryn mukaan uuden median narratiivisen verkon sydämessä ja siksi avain "uusien" lukutaitojen tukemisessa.

\section{Marjo Kovanen}

FM, erityisasiantuntija, Koulukino ry. 